\title{
HUBUNGAN ANTARA USIA DENGAN DETEKSI DINI KANKER SERVIKS METODE IVA
}

\author{
Relationship Between Age And Early Detection Of Servic Cancer Iva Method \\ Sab'ngatun ${ }^{1}$ Danik Riawati ${ }^{2}$ \\ ${ }^{1}$ STIKES Mamba'ul 'Ulum Surakarta ${ }^{2}$ Akademi Teknologi Bank Darah \\ Surakarta \\ sabngatun@yahoo.com
}

\begin{abstract}
ABSTRAK
Latar Belakang: Tingginya kasus baru kanker dan sekitar $40 \%$ dari kematian akibat kanker berkaitan dengan faktor resiko kanker yang seharusnya dapat dicegah. Upaya pencegahan dan pengendalian kanker di Indonesia khususnya untuk kanker leher rahim anatara lain dengan deteksi dini kanker leher rahim pada perempuan usia 30-50 tahun dengan menggunakan metode Papsemar dan inspeksi Visiaul dengan asam Asetat (IVA).

Tujuan penelitian ini untuk mengetahui hubungan antara usia dengan deteksi dini kanker serviks metode IVA.

Metode: Jenis penelitian ini adalah penelitian survey analitik dengan pendekatan retrospektif. Subjek dalam penelitian ini adalah semua ibu yang melakukan pemeriksaan di Poliklinik KIA KB Puskesmas Kebakkramat I Karanganyar pada bulan Maret 2019. Data diperoleh dari buku register kunjungan pada bulan Maret 2019. Pengolahan data dengan menggunakan Chi-Square.

Hasil : Hasil penelitian: mayoritas responden berusia $\leq 40$ tahun sebanyak 25 responden $(80,6 \%)$ dan mayoritas melakukan IVA tes sebanyak 18 responden $(58,1 \%)$. Hasil uji chi square dengan taraf signifikan 5\% adalah $0,02(\mathrm{p}<0,05)$ berarti terdapat hubungan yang signifikan antara usia dengan deteksi dini kanker serviks metode iva.

Simpulan: Ada hubungan yang signifikan antara usia dengan deteksi dini kanker serviks metode Iva.
\end{abstract}

Kata Kunci: usia, kanker serviks, iva

\section{ABSTRACT}

Background: The high number of new cases of cancer and about $40 \%$ of cancer deaths are related to cancer risk factors that could have been prevented. Cancer prevention and control efforts in Indonesia, especially for cervical cancer among other things with early detection of cervical cancer in women aged 30-50 years using the Papsemar method and Visiaul inspection with Acetic acid (IVA).

The purpose of this study was to determine the relationship between age and early detection of cervical cancer IVA method.

Method: This type of research is an analytic survey research with a retrospective approach. The subjects in this study were all mothers who examined at the KIA KB Polyclinic at Kebakkramat I Karanganyar Health Center in March 2019. 
Data was obtained from a visit registration book in March 2019. Data processing using Chi-Square.

Results: Results: the majority of respondents aged $\leq 40$ years were 25 respondents (80.6\%) and the majority did IVA tests of 18 respondents (58.1\%). Chi square test results with a significant level of 5\% is $0.02(p<0.05)$ meaning that there is a significant relationship between age and early detection of cervical cancer iva method.

Conclusion: There is a significant relationship between age and early detection of cervical cancer in the Iva method.

Keywords: age, cervical cancer, iva

\section{PENDAHULUAN}

Kejadian kanker sebesar 18,1 juta kasus baru dengan angka kematian sebesar 9,6 juta kematian di tahun 2018 dimana 1 dari 5 laki-laki dan 1 dari 6 perempuan di dunia mengalami kanker serta 1 dari 8 lelaki dan 1 dari 11 perempuan meninggal karena kanker. Angka kejadian penyakit kanker di Indonesia 136,2/100.000 penduduk berada pada urutan 8 di Asia tenggara sedangkan di Asia urutan ke 23. Angka kejadian kanker payudara sebesar 42,1/100.000 penduduk dengan rerata kematian 17/100.000 penduduk diikuti kanker leher rahim sebesar 23,4/100.000 penduduk dengan rerata kematian 13,9/100.000 penduduk. Berdasarkan data Riskesda prevalensi tumor/kanker di Indonesia menunjukkan adanya peningkatan dari 1,4/1000 penduduk di tahun 2013 menjadi 1,79/1000 penduduk pada tahun 2018. (Depkes, 2019)

Data kasus penyakit kanker di provinsi Jawa Tengah dari tahun ke tahun menunjukkan angka yang cukup tinggi, khususnya kasus kanker leher rahim. Berdasarkan laporan dan institusi pelayanan kesehatan di Jawa Tengah, pada tahun 2013 terdapat 1.934 kasus dan 2014 sebanyak 1.213 kasus. (Dinkes, 2015). Sedangkan angka kejadian kanker serviks di Kabupaten Karanganyar adalah 29 kasus pada tahun 2016 (Depkes, 2016)

Tingginya kasus baru kanker dan sekitar $40 \%$ dari kematian akibat kanker berkaitan dengan faktor resiko kanker yang seharusnya dapat dicegah. Faktor resiko kanker terdiri dari perilaku dan pola makan, diantaranya indeks massa tubuh tinggi, kurang konsumsi buah dan sayur, kurang aktivita fisik, pengunaan rokok, konsumsi alkohol berlebihan. (Pusdatin, 2015). Kesadaran dan pengetahuan masyarakat tentang kanker termasuk faktor risiko dan upaya pencegahannya dirasa masih kurang. Sebanyak 90-95\% faktor risiko kanker berhubungan dengan perilaku dan lingkungan. Karena itu perlu ada suatu gerakan bersama, menyeluruh dan berkesinambungan untuk meningkatkan kepedulian masyarakat terhadap kanker terutama kanker leher rahim. (Dinkes, 2015)

Mayoritas perempuan yang mengalami kanker leher rahim biasanya tidak melakukan skrining tes atau tidak melakukan tindak lanjut setelah ditemukan keadaan abnormal. Angka kejadian kanker serviks di Negara berkembang pada umumnya masih tinggi karena kendala sosial masyarakat dan ekonomi. Menurut Wilopo (2010) saat diperkirakan baru sekitar 5\% perempuan sudah melakukan skrining, sementara lebih dari satu decade yang lalu, lebih dari separoh wanita di Negara maju sudah melakukan skrining kanker serviks. (Emilia, 2010) 
Upaya pencegahan dan pengendalian kanker di Indonesia khususnya untuk kanker leher rahim anatara lain dengan deteksi dini kanker leher rahim pada perempuan usia 30-50 tahun dengan menggunakan metode Papsemar dan inspeksi Visiaul dengan asam Asetat (IVA). (Depkes, 2019) Upaya deteksi dini kanker payudara dan kanker serviks masih tergolong rendah. Cakupam metode IVA dan pemeriksaan payudara klinis (SADANIS) pada tahun 2017 hanya sekitar 8,1\% atau 3.038.296 orang. Padahal Indonesia menargetkan target nasional untuk deteksi dini kanker dapat menyasar 34 juta orang (Indriyani, 2018)

Pemeriksaan IVA dan Papsmear merupakan bagian dari deteksi dini kanker serviks yang disebabkan oleh infeksi virus Human Pappiloma Virus (HPV), yang dapat ditularkan baik melalui hubungan seksual maupun lewat kontak kulit ke kulit. Kanker ini bisa dicegah terutama jika kanker ditemukan dalam kondisi lesi prakanker. Jika ditemukan lesi prakanker atau pertumbuhan jaringan yang abnormal, maka bisa dihilangkan dengan krioterapi atau metode pendinginan. Kerioterapi akan menghancurkan lesi prakanker tanpa tindakan pembedahan dan sangat efektif untuk mencegah kanker serviks. Adanya lesi prakanker dapat diketahui saat melakukan deteksi dini kanker serviks dengan IVA dan Pap smear. Jadi IVA dan Papsmear memiliki dua fungi yaitu deteksi dini kanker serviks dan mencegah kanker serviks. (Dinkes, 2019)

Menurut WHO program pemeriksaan skrining yang dianjurkan untuk kanker serviks pada setiap wanita minimal satu kali pada usia 35-40 tahun, kalau fasilitas tersedia, lakukan tiap 10 tahun pada wanita usia 35-55 tahun, kalau fasilitas tersedia lebih dilakukan tiap 5 tahun pada wanita usia 35-55 tahun, ideal atau optimal skrining dilakukan tiap 3 tahun pada wanita usia 25-60 tahun (Emilia, 2010).

Menurut Kemkes (2013) pengendalian kanker payudara dan kanker serviks menargetkan minimal $80 \%$ perempuan usia 30-50 tahun melakukan deteksi dini setiap 5 tahun. Berdasarkan data Badan Pusat Statistik (BPS) tahun 2010, jumlah perempuan Indonesia yang berusia 30-50 tahun adalah sekitar 35 juta (35.950.765 orang). Sampai dengan tahun 2012 jumlah perempuan yang telah diskrining lebih dari 550 ribu orang (575.503 orang) dengan jumlah IVA (+) lebih dari 25 ribu orang (25.805 orang) atau 4,5\%), suspek kanker leher rahim $666(1,2$ per 1000) dan suspek tumor payudara 1.289 (2,2 per 1000).

Ketidaktahuan masyarakat dalam mengenali gejala kanker dan keengganan memeriksakan kesehatan secara rutin merupakan tantangan dalam upaya pengendalian kanker, untuk itu dibutuhkan kerjasama dan dukungan dari berbagai pihak. Cakupan deteksi dini IVA dan SADANIS di Indonesia sampai dengan tahun 2016 adalah 1.925 .943 orang aatu sekitar 5,2\% dari populasinya. Di Propinsi Jawa Tengah, cakupan deteksi dini hingga tahun 2016 adalah 280.847 orang atau sekitar 5,7\%, sedangkan Kabupaten Karanganyar selama tahun 2016 telah diperiksa sebanyak 3.571 orang atau 18,2\%. Seluruh Puskesmas Karanganyar telah memiliki tenaga terlatih dan sudah melaksanakan pelayanan deteksi dini kanker pada perempuan. (Depkes, 2017)

Berdasarkan latar belakang di atas, penulis tertarik mengambil judul "Hubungan Antara Usia Dengan Deteksi Dini Kanker Serviks Metode IVA." 


\section{METODE PENELITIAN}

Jenis penelitian ini adalah penelitian survey analitik dengan pendekatan retrospektif. Subjek dalam penelitian ini adalah semua ibu yang melakukan pemeriksaan di Poliklinik KIA KB Puskesmas Kebakkramat I Karanganyar pada bulan Maret 2019. Data diperoleh dari buku register kunjungan pada bulan Maret 2019. Pengolahan data dengan menggunakan Chi-Square.

\section{HASIL DAN PEMBAHASAN}

Tabel 1. Distribusi Frekuensi Usia Ibu

\begin{tabular}{|c|c|c|}
\hline Usia & Jumlah & Prosentase \\
\hline$<40$ tahun & 25 & 80.6 \\
\hline$\geq 40$ tahun & 6 & 19.4 \\
\hline Jumlah & 31 & 100 \\
\hline
\end{tabular}

Tabel 1 menunjukkan mayoritas usia ibu $<40$ tahun sebanyak 25 responden $(80,6 \%)$

Tabel 2. Pelaksanaan IVA Tes

\begin{tabular}{lcc}
\multicolumn{1}{c}{ IVA tes } & Jumlah & Prosentase \\
\hline Melakukan & 18 & 58.1 \\
Tidak Melakukan & 13 & 41.9 \\
Jumlah & 31 & 100 \\
\hline
\end{tabular}

Tabel 2 menunjukkan mayoritas responden melakukan IVA tes sebanyak 18 responden $(58,1 \%)$

Tabel 3. Uji Statsistik Hubungan Antar Usia dengan Deteksi Dini Kanker Serviks Metode IVA

\begin{tabular}{lccccc}
\hline & Value & df & $\begin{array}{l}\text { Asymp. } \\
\text { Sig. (2- } \\
\text { sided) }\end{array}$ & $\begin{array}{l}\text { Exact } \\
\text { Sig. (2 } \\
\text { sided) }\end{array}$ & $\begin{array}{l}\text { Exact } \\
\text { Sig. (1- } \\
\text { sided) }\end{array}$ \\
\hline Pearson Chi-Square & $5.373^{\mathrm{a}}$ & 1 & .020 & & \\
$\begin{array}{l}\text { Continuity Correction } \\
\text { Likelihood ratio }\end{array}$ & 3.450 & 1 & .063 & & \\
$\begin{array}{l}\text { Fisher Exact Test } \\
\text { Linear-by-Linear Association }\end{array}$ & 7.548 & 1 & .006 & & .028 \\
N of Valid Cases & 5.200 & 1 & .023 & & .025 \\
\hline
\end{tabular}

Tabel 3 menunjukkan adanya hubungan yang signifikan antara usia dengan deteksi dini kanker serviks dengan metode IVA dengan uji statistik Chi Square dengan $\mathrm{p}: 0,02$

Berdasarkan tabel 1. Mayoritas responden berusia $<40$ tahun. Dalam penelitian ini terdapat kelompok umur $<40$ tahun dan $>40$ tahun. Usia 40 tahun dijadikan batasan prevalensi kanker serviks karena kebanyakan kanker serviks menyerang wanita di atas usia 40 tahun. Dan bagi lesi pra kanker membutuhkan waktu 10-20 tahun untuk berubah menjadi kanker serviks, sehingga deteksi dini perlu waktu 10 tahun lebih awal atau dilakukan umur $<40$ tahun. Semakin tua 
umur seseorang, maka tingkat kekebalan tubuh mulai menurun, saat kekebalan tubuh mulai menurun maka virus HPV mudah menyerang tubuh. (Fauza, 2019)

Menurut Emilia (2010) Deteksi dini kanker serviks dengan menggunakan metode Inspeksi Visual Asam merupakan pilihan yang layak dilakkan di Negara berkembang, skrining ini ditujukan pada perempuan usia kurang dari 40 tahun. Penggunaan asam asetat (cuka) akan memperjelas perbedaan struktur sel dan absoprsi sehingga bila terdapat sel prakanker akan berubah menjadi putih.

Faktor resiko lain yang mempengaruhi kanker serviks adalah usia>35 tahun, usia pertama kali menikah melakukan hubungan seksual, aktivitas seksual yang tinggi, berganti-ganti pasangan, paritas, penggunaan kontrasepsi oral dan merokok. Semakin tua usia semakin meningkat resiko terjadinya kanker serviks (Kemkes, 2015).

Prevalensi penyakit kanker cukup tinggi pada kelompok umur 25-34 tahun, 35-44 tahun, 45-54 tahun. Kelompok umur tersebut lebih beresiko terkena kanker karena faktor perilaku dan pola amakan yang tidak sehat, kurang konsumsi sayur dan buah, proporsi penduduk yang merokok, obesitas, konsumsi lemak tinggi, kebiasaan konsumsi makanan yang dibakar/dipanggang dan konsumsi makanan hewani berpengawet (Pusdatin, 2015).

Perempuan yang berisiko terkena kanker serviks adalah usia diatas 30 tahun, dengan puncak usia tersering adalah 45-54 tahun dengan riwayat multipara dengan jadwal skrining IVA tes pada setiap wanita minimal satu kali pada usia 35-40 tahun. (Dinkes Buleleng, 2017). Pada penelitian ini banyak wanita usia <40 tahun melakukan IVA tes dikarenakan pada usia ini merupakan usia reproduksi sehat sebagai antisipasi pencegahan kanker serviks, responden melakukan IVA tes pada usia $<40$ tahun.

Berdasarkan tabel 2. Mayoritas ibu melakukan IVA tes. Responden memiliki kesadaran akan deteksi dini kanker payudara dengan IVA tes. Menurut Emilia (2010) kendala sosial masyarakat berkaitan dengan konsep tabu karena kanker serviks merupakan kanker yang menyerang bagian sensitive dan tertutup perempuan, perempuan tidak mudah untuk membuka diri untuk melakukan deteksi dini kanker serviks apalagi dilakukan oleh tenaga medis laki-laki, selain itu pengetahuan yang cukup atau kurang serta aspek kepercayaan masyarakat terhadap dokter belum merata serta kendala ekonomi menjadi kendala untuk melakukan skrining kanker serviks.

Hasil penelitian Rikandani (2017) terdapat 234 responden belum melakukan pemeriksaan IVA diantaranya 128 responden berpengetahuan rendah, 207 responden tidak mendapatkan dukungan suami, 135 responden memiliki sikap yang negattif, dan 145 responden belum pernah mendapatkan pendidikan kesehatan mengenai IVA tes.

Beberapa ibu belum mau melakukan deteksi dini kanker serviks dikarenakan malu karena organ reproduksinya dilihat orang lain, dan khawatir kalau pemeriksaan menimbulkan rasa sakit, serta takut kalau hasilnya posotif. (Mughis, 2017). Penelitian yang dilakukan oleh Yevin (2017) bahwa 55 responden belum melakukan IVA tes diperoleh 20 responden (36\%) karena takut, 6 responden (11\%) dikarenakan malu, 29 responden (53\%) tidak tahu mengenai IVA tes. 
Berdasakan tabel 3. Hasil uji chi square dengan taraf signifikan 5\% adalah $0,02<0,05$ berarti terdapat hubungan antara usia dengan deteksi dini kanker serviks metode iva.

Dari hasil penelitian ini yang melakukan deteksi dini kanker serviks dengan metode IVA kebanyakan berusia kurang dari 40 tahun. Hal ini dikarenakan kanker serviks biasanya diketahui sudah dalam stadium lanjut, dan pada usia 35-55 tahun memiliki resiko 2-3 kali lipat untuk menderita kanker serviks. Pada usia yang semakin tua khususnya usia lanjut/menopause, pada masa ini terjadi perubahan sel-sel abnormal pada mulut rahim. Sehingga pada usia reproduksi pasien ini dengan sadar melakukan deteksi dini kanker serviks dengan metode IVA.

Kanker serviks sering terjadi pada usia di atas 40 tahun, dan dysplasia umumnya terdeteksi 10 tahun sebelum berkembang menjadi kanker. Dysplasia paling sering terjadi pada perempuan usia sekitar 35 tahun. Sehingga skrining difokuskan pada perempuan usia 30-40 tahun.

Iva tes adalah metode deteksi dini kanker serviks dengan mengoleskan asam asetat lima persen pada leher rahim (serviks) kemudian ditunggu 30 sampai 60 detik untuk melihat reaksi leher rahim, jika terjadi perubahan warna menjadi putih pada bagian yang terkena olesan asam asetat berarti menunjukkan adanya lesi pra kanker, tetapi jika tidak ada perubahan warna berarti leher rahim dalam keadaaan normal. Pemeriksaan iva ini bisa dilakukan oleh dokter maupun bidan. (Depkes, 2009)

Menurut hasil penelitian Lestari (2017) jumlah pemeriksaan IVA dengan kategori usia reproduksi dengan minat rendah sebanyak 43 orang $(53,8 \%)$, hasil statistic menunjukkan terdapat hubungan yang signifikan antara usia dengan minat pemeriksaan IVA ( $p$ value $=0.003$ ) peneliti menganalisis bahwa kanker serviks sering menyerang wanita terutama pada usia produktif, selain itu karena usia seseorang relative tua maka akan mempengaruhi minat melakukan tes IVA karena mereka beranggapan pemeriksaan IVA hanya untuk wanita yang masih muda saja.

Sesuai hasil penelitian Lisminawati (2016) mayoritas memiliki minat tinggi sebanyak 35 orang $(87,5 \%)$. Minat seseorang dalam melakukan deteksi dini kanker serviks khususnya IVA tinggi pengaruhnya dengan keinginan yang keluar dari diri masing-masing orang juga dipengaruhi oleh kesadaran seseorang tentang kesehatan dirinya, sehingga diharapkan jika seseorang mempunyai minat yang tinggi tentang IVA tes ia akan benar benar melakukan tes IVA secara rutin. Keikutsertaan seseorang dalam mengikuti IVA besar pengaruhnya oleh tinggi rendahnya minat seseorang.

\section{SIMPULAN DAN SARAN}

\section{Simpulan}

Hasil penelitian ini mayoritas responden berusia $\leq 40$ tahun sebanyak 25 responden $(80,6 \%)$ dan mayoritas melakukan IVA tes sebanyak 18 responden $(58,1 \%)$. Hasil uji chi square dengan taraf signifikan 5\% adalah $0,02(\mathrm{p}<0,05)$ berarti terdapat hubungan antara usia dengan deteksi dini kanker serviks metode iva. 


\section{Saran}

Diharapkan Puskesmas lebih meningkatkan promosi kesehatan tentang kanker serviks dan metode deteksi dini kanker serviks dengan IVA tes. Dan diharapkan responden lebih meningkatkan pengetahuannya tentang kanker serviks serta deteksi dini kanker serviks dengan metode IVA tes.

\section{DAFTAR PUSTAKA}

Astuti Indriyani. 2018. Deteksi Dini Kanker Masih Jauh dari Target http://mediaindonesia.com/read/detail/143244-deteksi-dini-kanker-masih-

jauh-dari-target

Depkes. 2016. Profil Kesehatan Kabupaten Karanganyar Tahun 2016 http://www.depkes.go.id/resources/download/profil/PROFIL_KAB_KOT A_2016/3313 Jateng_Kab_Karanganyar_2016.pdf

Depkes. 2017. Kunjungi Karanganyar, Ibu Negara Tunjukkan Dukungan Terhadap Pengendalian Kanker http://www.depkes.go.id/article/view/17022400003/the-first-lady-showsher-support-to-cancer-control-when-visiting-karanganyar.html

Depkes, 2019. Deteksi Dini Cegah Kanker http://www.depkes.go.id/article/view/19020500001/deteksi-dini-cegahkanker.html

Depkes, 2019. Hari Kanker Sedunia, 2019 http://www.depkes.go.id/article/view/19020100003/hari-kanker-sedunia2019.html

Dinkes. 2019. Pertemuan Lintas Sektor Untuk Meningkatkan Cakupan Pemeriksaan IVA Tes Dan Pap Smear tahun 2019 http://dinkes.semarangkota.go.id/index.php/content/post/138

Emilia, Ova, dkk. 2010. Bebas Ancaman Kanker Serviks. Fakta, pencegahan dan Penanganan Dini Serangan Kanker Serviks. Yogyakarta : MedPress.

Kemkes, 2015. Panduan Program Nasional Gerakan Pencegahan Dan Deteksi Dini Kanker Leher Rahim Dan Kanker Payudara http://p2ptm.kemkes.go.id/uploads/2016/10/Panduan-Program-NasionalGerakan-Pencegahan-dan-Deteksi-Dini-Kanker-Kanker-Leher-Rahim-danKanker-Payudara-21-April-2015.pdf

Kemkes, 2013. Pemerintah Targetkan 80\% Perempuan Dapat Deteksi Dini Kanker Payudara Dan Kanker Serviks http://www.kemkes.go.id/development/site/jkn/index.php?cid=13100003\& id=pemerintah-targetkan-80\%-perempuan-dapat-deteksi-dini-kankerpayudara-dan-kanker-serviks.html

Lisminawati, Heni. 2016. Pengetahuan, Minat Dan Keikutsertaan Melakukan Tes Iva Pada Perempuan Pasca Penyuluhan Tentang Kanker Serviks Di Desa Caturharjo Sleman Yogyakarta, Prodi DIV Bidan Pendidik. Universitas 'Aisyiyah Yogyakarta. http://digilib.unisayogya.ac.id/1998/1/NASKAH\%20PUBLIKASI\%20HE NY\%20LISMINAWATI\%20\%28201510104294\%29.pdf 